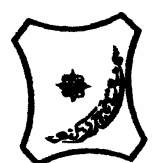

Bayero Journal of Pure and Applied Sciences, 6(2): 57 - 64

Received: May 2013

Accepted: September 2013

ISSN $2006-6996$

\title{
DETERMINATION OF HEAVY METALS IN SOILS FROM DUMP SITE OF TANNERIES AND FARMLANDS IN CHALLAWA INDUSTRIAL ESTATE KANO,NIGERIA
}

\author{
Isa, Koki ${ }^{1}$ and Jimoh, W. L. O. ${ }^{2}$ \\ ${ }^{1}$ Department of Chemistry North West University Kano \\ ${ }^{2}$ Department of Pure and Industrial Chemistry, Bayero University P.M.B 3011-Kano \\ Correspondence author: isakoki@yahoo.com
}

\begin{abstract}
Heavy metals were determined in soil samples at the dump site, Challawa town, Karfi Irrigation site and farmlands near the dump site by flame Atomic Absorption Spectrophotometer (AAS). The results showed that soil at the dump site contains significant amount of toxic elements. Hence remediation processes were suggested. The soil samples were analyzed for the presence of $\mathrm{Cd}, \mathrm{Cu}$, $\mathrm{Cr}, \mathrm{Pb}, \mathrm{Fe}$ and $\mathrm{Zn}$. The concentrations were $9.21 \pm 0.52 \mathrm{\mu gg}^{-1}$ to $3797.33 \pm 459.20 \mathrm{\mu gg}^{-1}$ for chromium, $0.39 \pm 4.96 \mu g^{-1}$ to $40.65 \pm 12.03 \mu g^{-1}$ for lead, $0.10 \pm 0.82 \mu g^{-1}$ to $1.96 \pm 0.82 \mu g g^{-1}$ for cadmium, $0.36 \pm 0.09 \mu g^{-1}$ to $15.99 \pm 5.29 \mu g g^{-1}$ for copper, $13.69 \pm 2.03 \mu g g^{-1}$ to $23.32 \pm 2.33 \mu g g^{1}$ for zinc and iron concentration was $1165.00 \pm 249.53 \mu g^{-1}$ to $2542.50 \pm 208.71 \mu g g^{-1}$. The concentrations of the metals in the soil samples analyzed was found to be in the order $\mathrm{Cr}>\mathrm{Fe}>\mathrm{Zn}>\mathrm{Cu}>\mathrm{Pb}>\mathrm{Cd}$. Heavy metals are known to cause many diseases, and are poisonous even at low concentrations.

Keywords; Heavy metals, Challawa, Karfi, Tanneries,Soil, and Irrigation.
\end{abstract}

\section{INTRODUCTION}

Purity of our environment such as air, water and soil are of great importance, as each of these components possesses both physical and chemical properties that make life of the living organism most suitable and comfortable (Butler, 1970).

The rapid development in industrialization has caused tremendous increase in the release of pollutants. These pollutants are present in concentration that cause harm to human, animal and plant lives and to non-living organisms. Environmental pollution is therefore the presence of toxic substances, naturally or due to man's activities in the environment at a level where acute toxic effect can be recognized (Higgens and Burns, 1979).

Heavy metals can enter water supply from industrial and domestic wastes, or even from acid rain breaking down soils and releasing heavy metals into streams, lakes, rivers and ground water. Anthropogenic activities (i.e. farming) also affect the natural geological and biological redistribution of heavy metals in the environment. Such alteration often affected the heavy metal toxicity by allowing it to bio-accumulate in plants and animals, bio concentrate in the food chain or attack specific organs of the body (Hawkes, 1997).

Heavy metals discharge to the environment may occur as a result of normal geological phenomena such as leaching and ore formation. Metals are released into the environment by burning of fossils, mining and application of pesticides and domestic wastes (Duffus, 1980).

Tanneries are major sources of highly toxic and hazardous solid wastes. They produce animal's residues from such operations as cleaning, fleshing, splitting, tanning, shaving and buffing. Each of these operations generates waste products, which must be disposed of. Solid wastes of animal origin are powerful pollutants in water and soil, and produce odour when they decompose (Naidu et al., 2000).

Of the heavy metals tanneries have been found to discharge, not only chromium, which is an inherent product of tanning process, are significant amounts of $\mathrm{Zn}, \mathrm{Cu}, \mathrm{Mn}$ and $\mathrm{Pb}$. High levels of $\mathrm{Cr}\left(2940 \mathrm{mgl}^{-1}\right)$ with $\mathrm{Zn}, \mathrm{Cu}$ and $\mathrm{Pb}$ have been detected at the main waste disposal point in Bangladesh, exceeding the toxic level range in soils. Many of these heavy metals are being carried down to the ground water and are causing severe environmental concern (Kashem, 1996).

Toxic metals do not occur naturally in soils but are actually carried by waste water flow from industries to rivers, streams and lakes which are used for irrigation purposes in agriculture. These heavy metals are in turn taken up from the soil by plant roots, and passed to stems and leaves, which are eventually consumed by animals and humans (Folaranmi et al., 2002).

This work therefore detected the presence of some heavy metals and their various concentrations in soil at dump site, the surrounding tanneries in Challawa, and Karfi town of Kura L.G.A. of Kano State. 


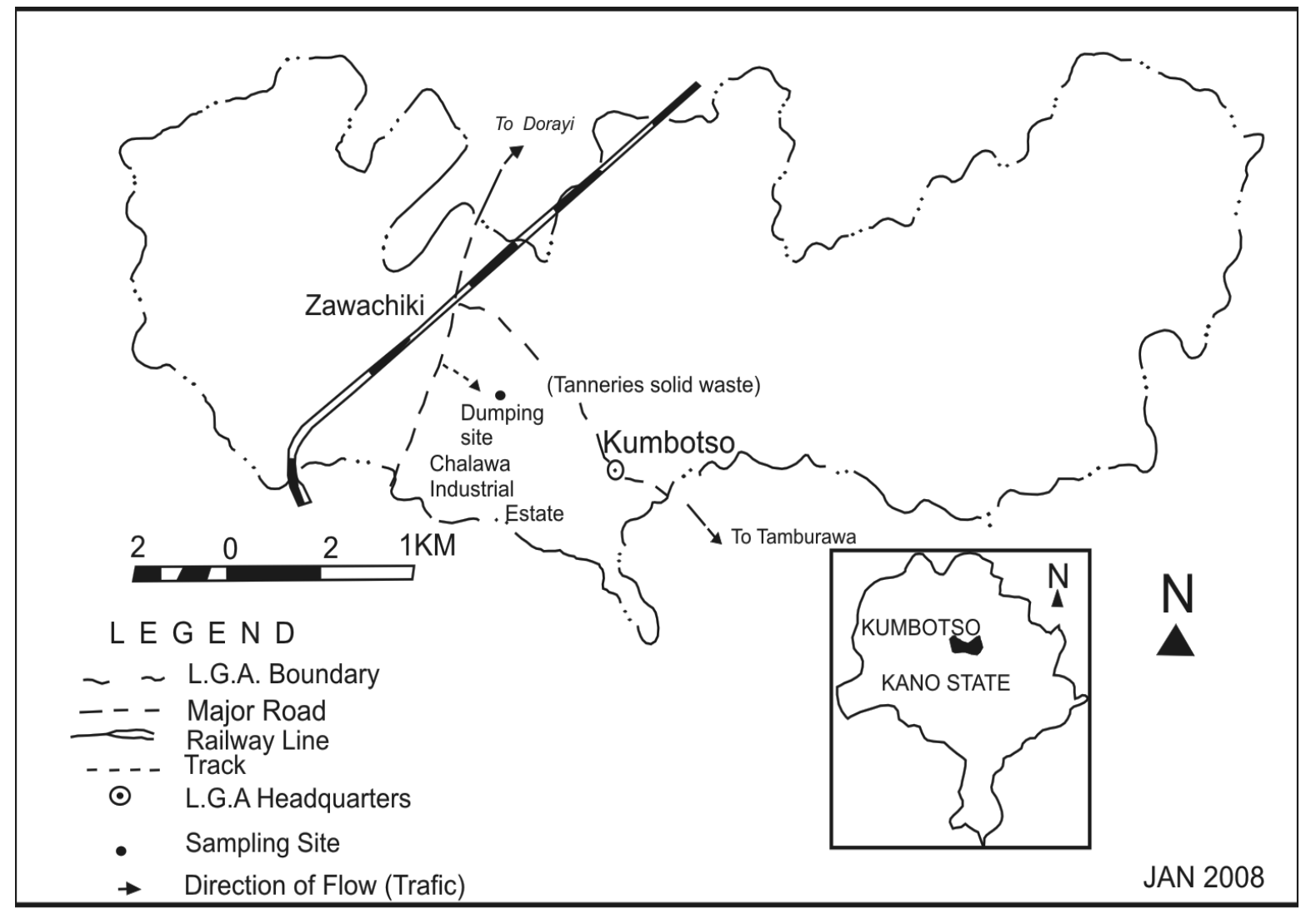

Figure 1: Kumbotso L.G.A.Showing The Sampling Sites

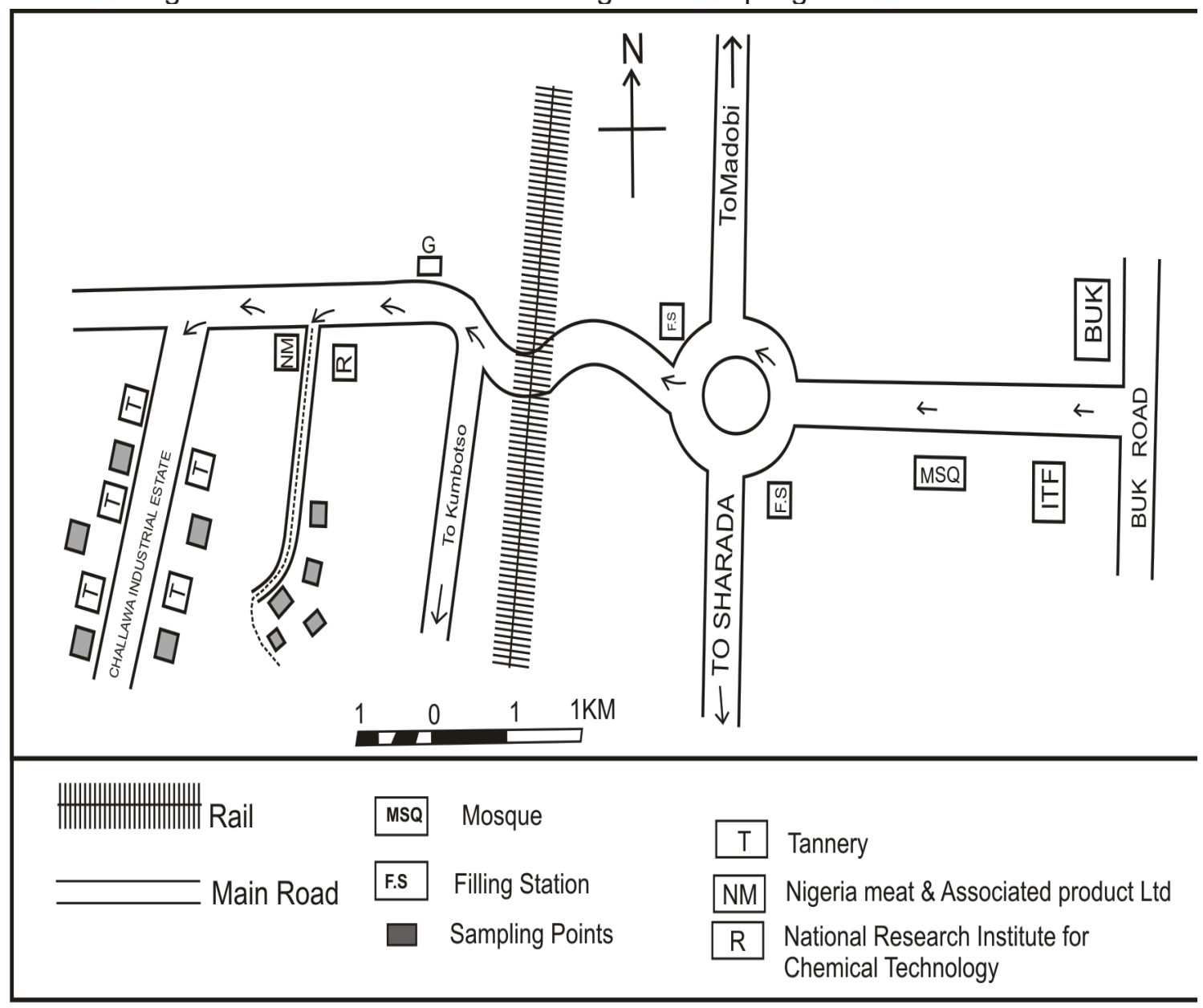

Fig. 2: Sketch Of The Study Area Showing Dump Site At Challawa Industrial Estate 


\section{MATERIALS AND METHODS}

The study area as shown in figure 1 and 2 existed for many decades as a dumping site of tanneries at Challawa Industrial estate in Kumbotso Local Government Area of Kano State. The area is dominated with tanneries that process skin and hide, discharging their effluent to the streams and depositing other solid wastes in the farmlands which are subsequently used by our local farmers as manure. Also Karfi irrigation site which is predominantly a farming area both in dry and rainy season.

\section{Sampling Sites}

The study area is the dump site of tanneries in Challawa industrial estate in Kumbotso local government area of Kano state. Kumbotso local government area lies between latitudes $11^{\circ} 50^{\prime}$ to $12^{\circ}$ $\mathrm{N}$ and longitude $8^{\circ} 24^{\prime} \mathrm{W}$ to $8^{\circ} 40^{\prime} \mathrm{E}$. It falls within Kano settlement zone bordering the south and west by Madobi, Nothwest by Rimingado and North by Gwale and East by Tarauni local government areas respectively. The sampling zone covers an area of $30,072 \mathrm{~m}^{2}$. While Karfi irrigation site is situated in Kura local government area of Kano with an area of $206 \mathrm{~km}^{2}$.

\section{Samples Collection}

Soil samples were collected randomly from different locations of the dumping site, farmland and the surrounding tanneries. Three soil samples were collected around the dumping site $10 \mathrm{~m}$ away from each sampling point. Also, soil was sampled as a control from Karfi town.

\section{Sample Treatment}

Soil samples obtained were air dried and crushed to pass through $2 \mathrm{~mm}$ sieve (Dikko and Ibrahim, 1999).

\section{Digestion of Samples and Determination of Concentrations}

Dried soil sample $(0.2 \mathrm{~g})$ was accurately weighted into platinum crucible. Few drops of de-ionized water were added to dampen the sample. 6 Centimeter cube of concentrated $\mathrm{HCl}$ acid and $1 \mathrm{~cm}^{3}$ of hydrofluoric acid were added. The mixture was heated on a hot plate. After cooling, $5 \mathrm{~cm}^{3}$ of hydrofluoric acid $1 \mathrm{~cm}^{3}$ concentrated $\mathrm{HCl}$ acids were heated on a sand - bath at a temperature of $200-230^{\circ} \mathrm{C}$ until the acids evaporated to dryness. Six centimeter cure $\left(6 \mathrm{~cm}^{3}\right)$ hydrochloric acid $\left(1 \mathrm{moldm}^{-3}\right)$ was added after cooling and the resulting was boiled for 10 minutes. It was filtered, made up to mark with de-ionized water in a $25 \mathrm{~cm}^{3}$ volumetric flask. The sample solutions were analyzed using Atomic Absorption Spectrophotometer Varian 1200 with air acetylene flame (Jimoh and Mohammad, 2011).

\section{RESULTS AND DISCUSSION}

The result of heavy metal contents in the soils analyzed are shown in Table 1 . Based on the results of this study, it is evident that some heavy metals occurred above the natural occurring values, this is indicating pollution of the study area.

Some of the metals are essential for the growth of plant, but they can cause harmful effect when in excess.

The result showed that $\mathrm{Cr}$ and $\mathrm{Zn}$ were present in considerable amount in the soil.

Very low concentration of $\mathrm{Cr}$ and $\mathrm{Cu}$ was determined in the soil from Karfi town (control). This is so because of the wide use of chemicals containing heavy metals in the tannery operations. It is therefore of paramount importance to consider the intake of the metals in food due to absorption by plants from contaminated soil (Folaranmi et al., 2002), or in water due to leaching of the metals to the underground water and to the streams.

Table 1: Concentration $\left(\mu_{g g}{ }^{-1}\right)$ of Metals in Soil Samples from the Sampling Sites .

\begin{tabular}{|c|c|c|c|c|c|c|}
\hline Sample Code & $\mathrm{Cr}$ & $\mathbf{P b}$ & Cd & $\mathbf{C u}$ & Zn & $\mathbf{F e}$ \\
\hline $\begin{array}{l}\text { Q (Challawa } \\
\text { Town) }\end{array}$ & $32.79 \pm 0.96$ & ND & ND & $0.36 \pm 0.09$ & $17.82 \pm 3.06$ & $1507.50 \pm 68.34$ \\
\hline $\begin{array}{l}A B \quad \text { Karfi } \\
\text { Irrigation Site) }\end{array}$ & $239.54 \pm 9.61$ & $1.52 \pm 0.19$ & ND & $2.01 \pm 0.17$ & $23.32 \pm 2.33$ & $1767.50 \pm 121.87$ \\
\hline S (Karfi Town) & $9.21 \pm 0.52$ & ND & ND & $0.19 \pm 0.03$ & $23.23 \pm 1.43$ & $1595.00 \pm 62.10$ \\
\hline $\begin{array}{l}X \text { (Vicinity of } \\
\text { Tanneries) }\end{array}$ & $2523.33 \pm 307.61$ & $12.35 \pm 4.96$ & $0.15 \pm 0.00$ & $15.99 \pm 5.29$ & $19.37 \pm 1.28$ & $1810.00 \pm 249.53$ \\
\hline $\begin{array}{l}Z \text { ( }(5 m \text { away from } \\
X)\end{array}$ & $2489.54 \pm 307.61$ & $2.16 \pm 4.96$ & ND & $6.53 \pm 5.29$ & $16.27 \pm 1.28$ & $1165.00 \pm 249.53$ \\
\hline $\begin{array}{l}\text { AA (5m away } \\
\text { from Z) }\end{array}$ & $3076.63 \pm 307.61$ & $0.46 \pm 4.96$ & ND & $3.28 \pm 5.29$ & $19.27 \pm 1.28$ & $1725.00 \pm 249.53$ \\
\hline $\begin{array}{l}\text { T ( } 5 \mathrm{~m} \text { away from } \\
\mathrm{AA})\end{array}$ & $2232.89 \pm 307.61$ & $0.39 \pm 4.96$ & ND & $2.81 \pm 5.29$ & $16.66 \pm 1.29$ & $1634.50 \pm 249.53$ \\
\hline W (Dump Site) & $3278.43 \pm 459.20$ & $21.94 \pm 12.03$ & $1.96 \pm 0.82$ & $3.42 \pm 1.24$ & $18.66 \pm 2.03$ & $2415.00 \pm 208.71$ \\
\hline $\begin{array}{l}\text { Y (10m away } \\
\text { from W) }\end{array}$ & $3797.33 \pm 459.20$ & $11.58 \pm 12.03$ & $0.39 \pm 0.82$ & $0.49 \pm 1.24$ & $13.69 \pm 2.03$ & $2542.50 \pm 208.71$ \\
\hline $\begin{array}{l}U(10 m \text { away } \\
\text { from } Y)\end{array}$ & $2578.84 \pm 459.20$ & $40.65 \pm 12.03$ & $0.10 \pm 0.82$ & $2.65 \pm 1.24$ & $16.23 \pm 2.03$ & $2050.00 \pm 208.71$ \\
\hline $\begin{array}{l}\mathrm{R} \text { (Farm near } \\
\text { dump site) }\end{array}$ & $2413.89 \pm 54.26$ & $0.49 \pm 0.10$ & ND & $0.36 \pm 0.08$ & $21.61 \pm 1.49$ & $2197.50 \pm 163.45$ \\
\hline
\end{tabular}


Table 2: Upper Permissible Values for Concentration of Heavy Metals in Agricultural Soil with pH 6 to 7.

\begin{tabular}{ll}
\hline Metal & Concentration $\left.\mathbf{~}_{\mathbf{\mu g g}} \mathbf{- 1}\right)$ \\
\hline Cadmium & $3-5$ \\
Copper & $50-140$ \\
Nickel & $30-75$ \\
Zinc & $150-300$ \\
Mercury & $1-1.5$ \\
Lead & $50-300$ \\
Chromium & 600 \\
\hline
\end{tabular}

Sources: Commission of the European community; UK Statutory Instrument No. 1263; UK department of the environment; FRG Klarsch ammverordnung.

Chromium distribution patterns for various samples in Fig 3 show that most of the samples analyzed have high concentration exceeding the maximum threshold limits prescribed by United State Environmental Protection Agency of $1500 \mathrm{ugg}^{-1}$ (USEPA, 1993), and UK Department of Environment of $600 \mathrm{\mu gg}^{-1}$ (UKDOE, 1987). Soil from contaminated site has the highest concentration of $3797 \mu_{g g g^{-1}}$ and soil from Karfi town is the lowest with $9.20 \mu^{-1} g^{-1}$.Chromium concentration was found to decrease at a distance of $10 \mathrm{~m}$ away from the dump site, but show no definite pattern at a distance of $5 \mathrm{~m}$ away from the vicinity of the tanneries. The highest concentration of chromium could attributed to it been the major tanning agent used. Long term exposure to Chromium causes damage to the kidney, liver and nerve tissues. If continuously exposed to it, humans may develop nasal perforation and bronchiogenic carcinomas (Sindhu, 2005).

The distribution pattern of lead in the soil samples as shown in Fig. 4 indicates that some values are higher than toxicity characteristic leachate limit (TCL) of $5.00 \mu g^{-1}$ for lead (Bowen, 1979). Soil from the contaminated site has the highest concentration of $40.65 \mathrm{\mu gg}^{-1}$ and the lowest is soil within the surrounding tanneries with $0.38 \mu \mathrm{gg}^{-1}$. This implies that waste containing lead might have been introduced to the environment. Lead concentration was found to decrease $5 \mathrm{~m}$ away from the vicinity of the tanneries, but show no definite pattern $10 \mathrm{~m}$ away from the dump site. The pollution of soil by lead is very serious problem that has been given much attention by environmental chemists. This is due to the fact that lead is a cumulative pollutant (Dara, 1993). Lead causes abdominal pain, anemia, anorexia, bone pain, brain damage, confusion, etc.

The concentration of cadmium in soil of the study area as shown in Fig. 5 is from 0.103 to $1.90 \mathrm{ugg}^{-1}$. Naturally occurring cadmium concentration ranges from 0.03 to $0.30 \mu \mathrm{gg}^{-1}$. Cadmium concentrations in the soils analyzed were found to be far above the naturally occurring range. This is pollution especially when cadmium is known to be one of the most harmful pollutants, though cadmium was not detected in some of the soil samples analyzed. Cadmium was not detected $5 \mathrm{~m}$ away from vicinity of the tannery, but its concentration decrease at an interval of $10 \mathrm{~m}$ away from the dump site. Cadmium is known to cause itai-itai disease, (Jun, 1969; Jun, 1974; Gustav, 1974; Ademoroti, 1988).

Cadmium causes dry and scaly skin, loss of sense of smell, hair loss and pain in the back.

The distribution pattern of copper in the soil samples in Fig. 6 shows that the values are within the normal range of $5.00-20.00 \mathrm{\mu gg}^{-1}$ required by plants in natural soil concentration (Bowen, 1979). Copper was present in all the samples analyzed, its concentration decreases $5 \mathrm{~m}$ away from the vicinity of the tannery, and show no definite pattern away from the dump site. In high doses Copper causes anemia, liver, kidney damage, stomach and intestinal irritation. The distribution pattern of Zinc in soil samples is shown in Fig. 7. Concentrations of Zinc in various samples are within the natural range of 1.00 to $9.00 \mu g^{-1}$ in soil (Bowen, 1979).Zinc was present in all the soil samples analyzed, and its concentration show no definite pattern $5 \mathrm{~m}$ away from the vicinity of the tannery and $10 \mathrm{~m}$ away from the dump site. Excess amount of Zinc in man causes anemia, exposure to excessive zinc fumes leads to nausea, eyes throats, pain and constriction in the chest with coughing and labored breathing. Crops grown on soil with excess zinc may suffer from leaves and retarded growth and translocation of iron in the plant (Asia et al 2007).

The distribution pattern of iron for various samples as shown in Fig. 8 reveals high concentration of iron in the soil. Soil from the contaminated site has the highest concentration of $2542 \mu g^{-1}$ and the lowest is soil around the tanneries with $1165 \mu \mathrm{gg}^{-1}$. Iron was present in all the soil samples analyzed, and its concentration show no definite pattern $5 \mathrm{~m}$ away from the vicinity of the tannery and $10 \mathrm{~m}$ away from the dump site. The detected concentration might be due to the natural background concentration of iron in the environment. It has been confirmed that natural soils contain significant concentration of iron (Aluko et al., 2003; Dara, 1993; Eddy, 2004). Eddy (2004) suggested that the pollution of environment by iron cannot be conclusively linked to waste material alone but other natural sources of iron must be taken into consideration. Iron is a very useful component of the blood and may be toxic by taking sources outside the normal food supply. Exposure to Iron dust causes respiratory diseases, such as chronic bronchitis and ventilation difficulties. 


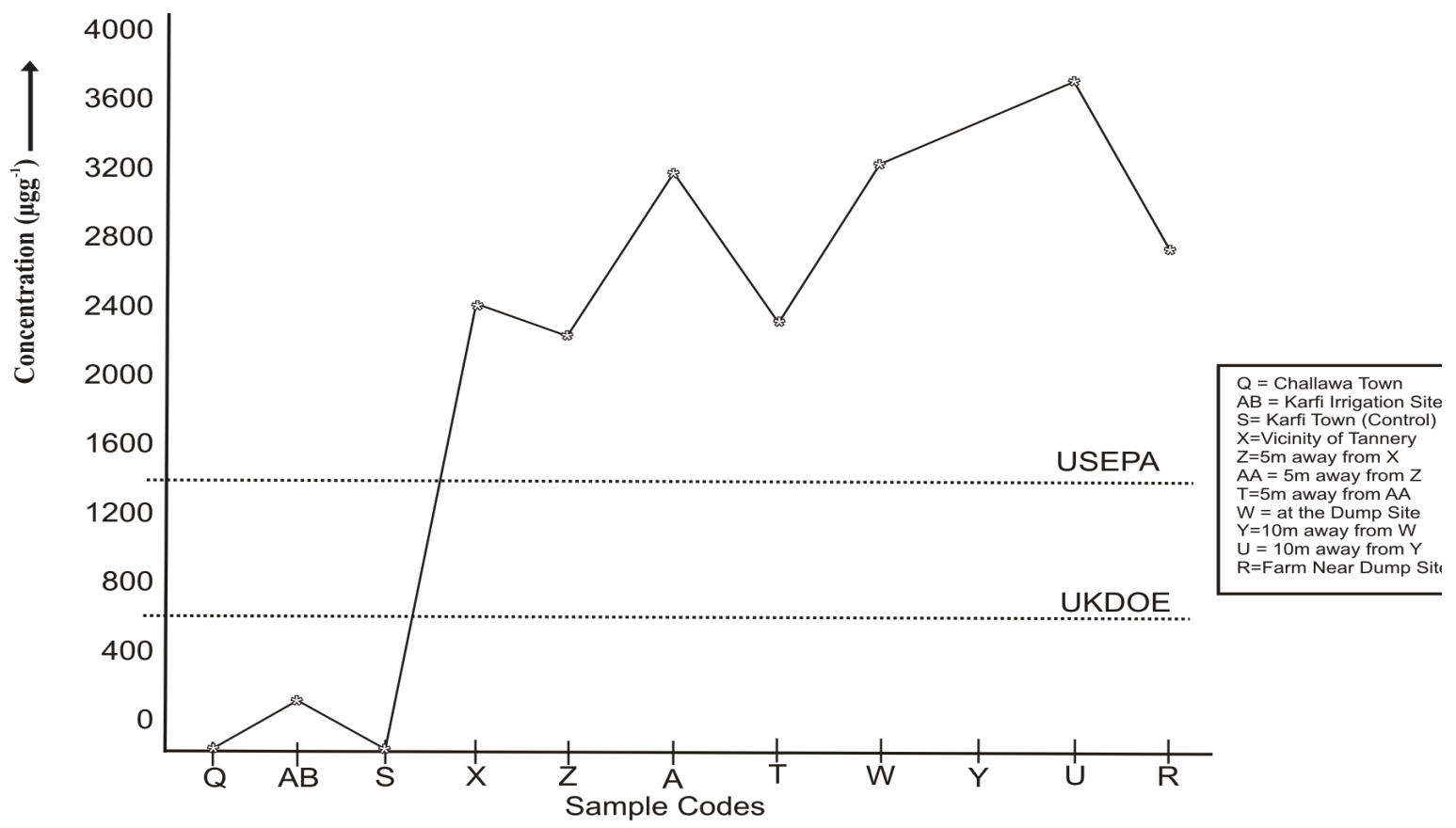

Fig. 3: Distribution Of Chromium In Various Soil Samples

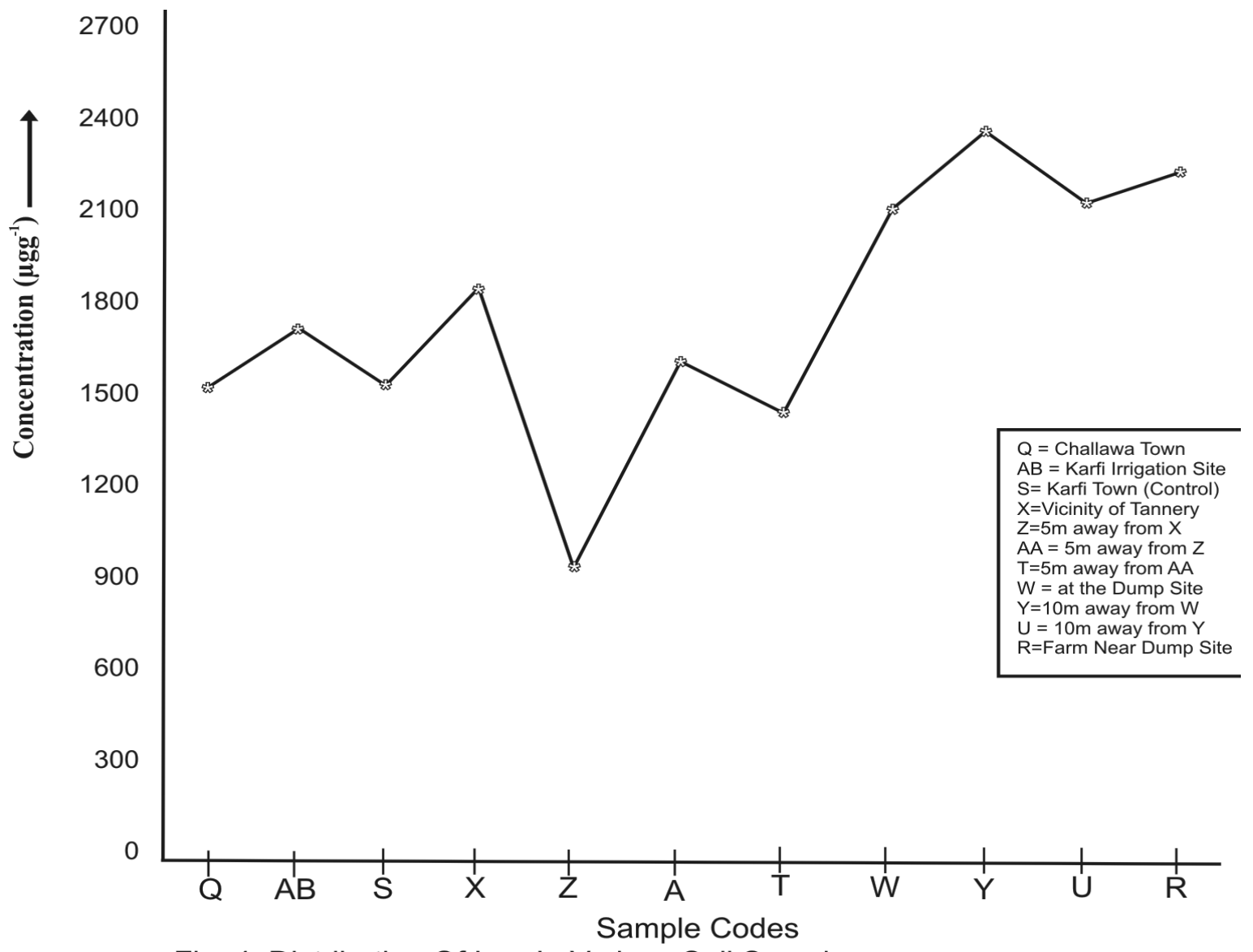

Fig. 4: Distribution Of Iron In Various Soil Samples 
Bajopas Volume 6 Number 2 December, 2013

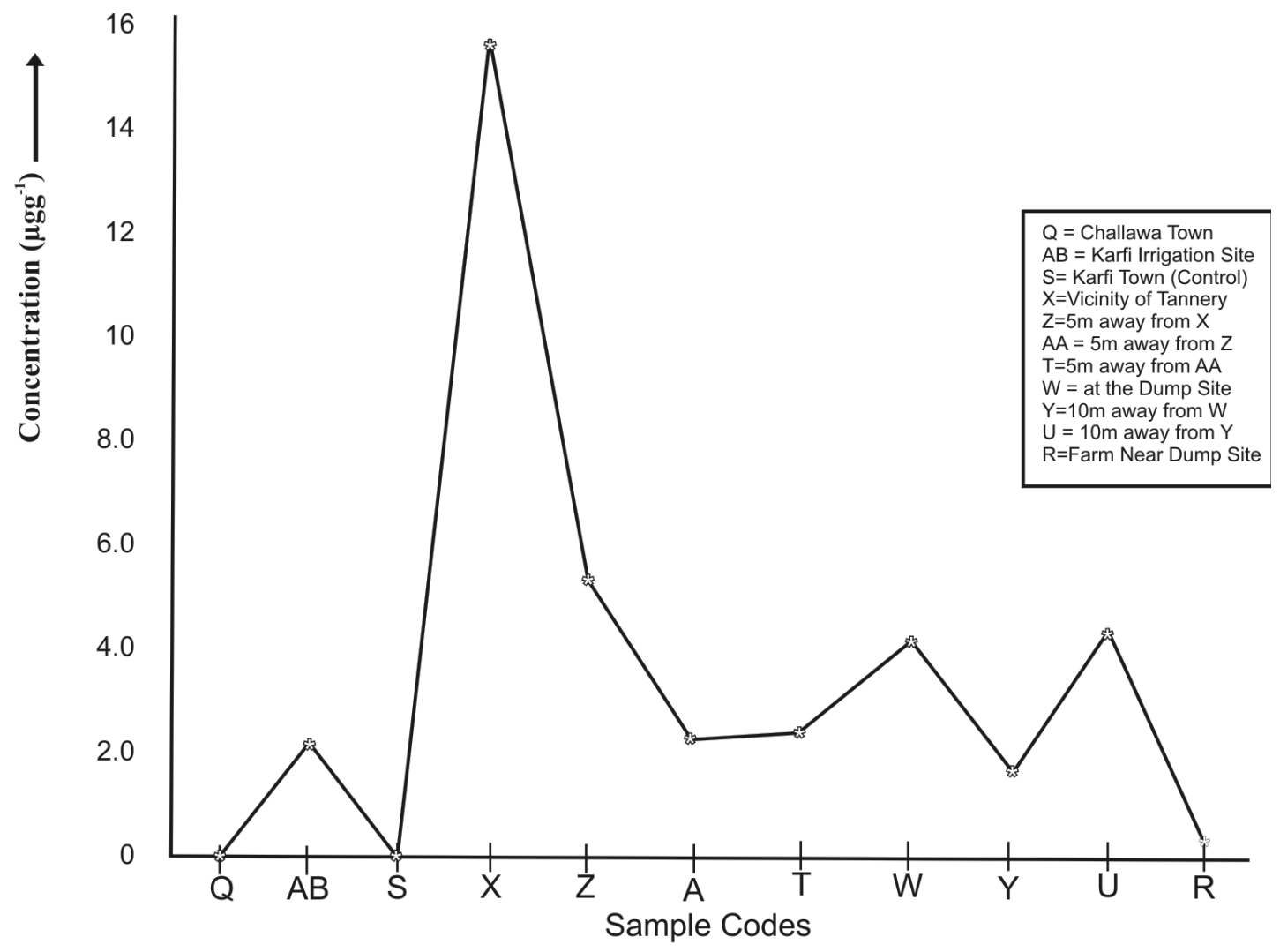

Fig. 5: Distribution Of Copper In Various Soil Samples

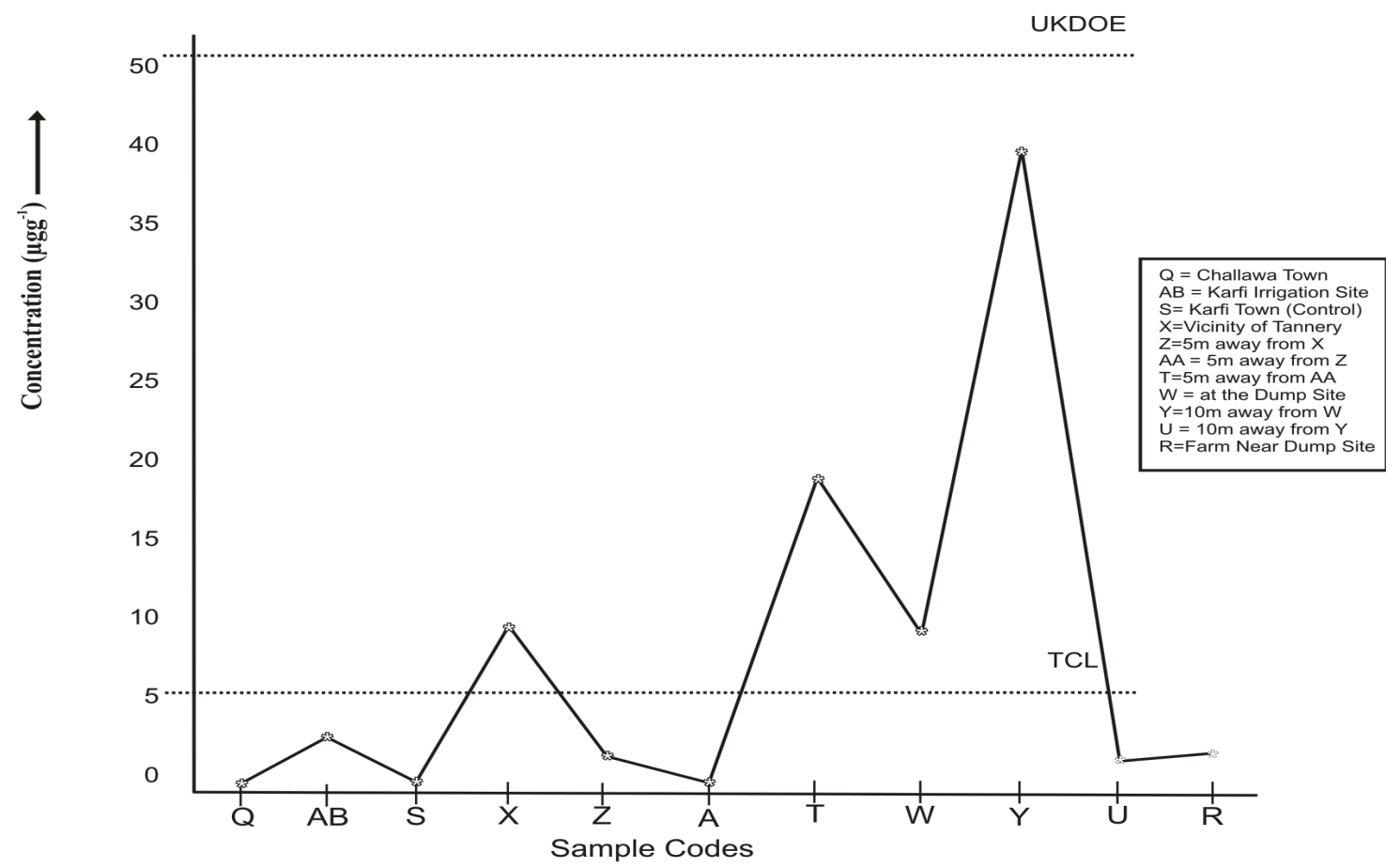

Fig. 6: Distribution Of Lead In Various Soil Samples 


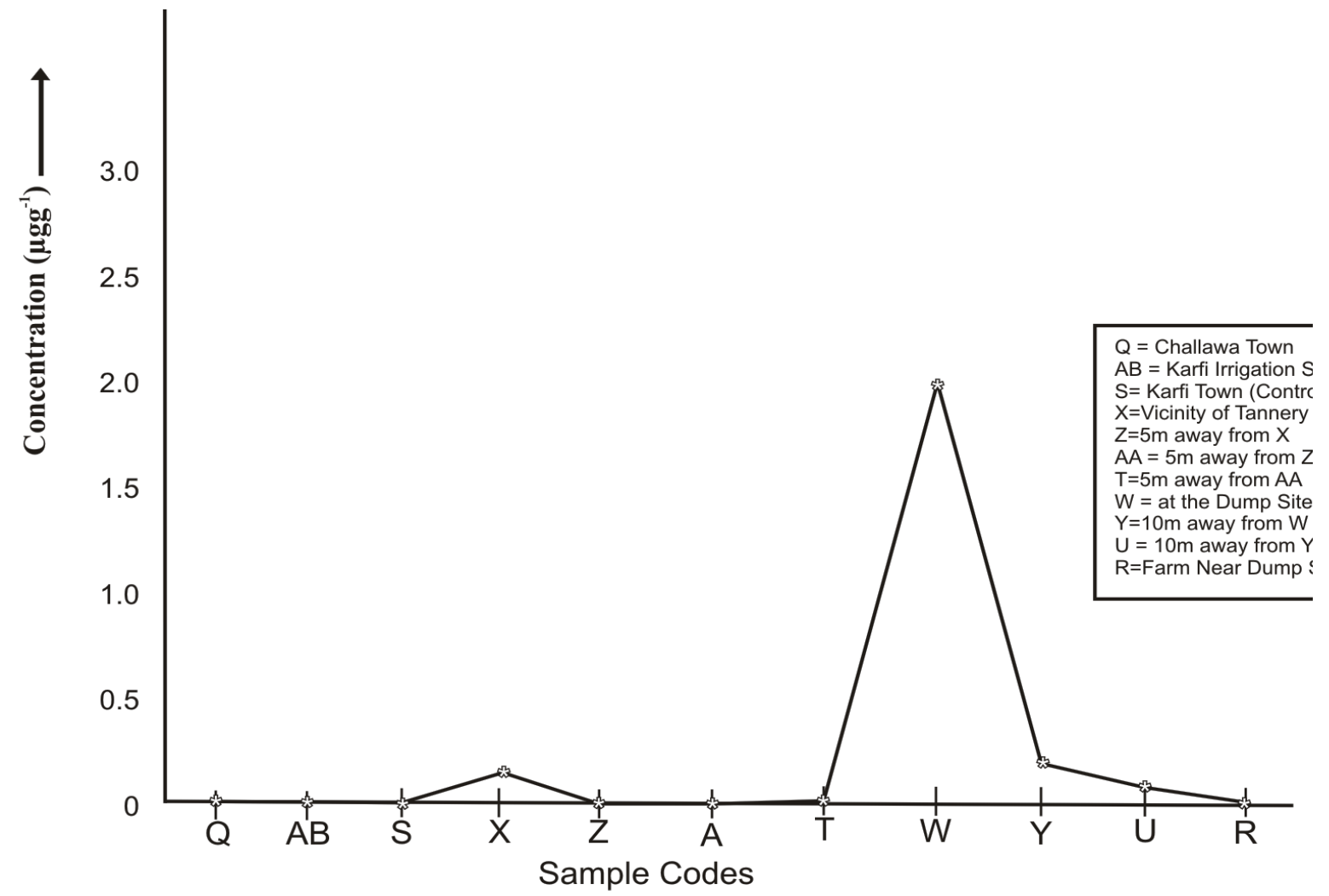

Fig.7: Distribution Of Cadmium In Various Soil Samples

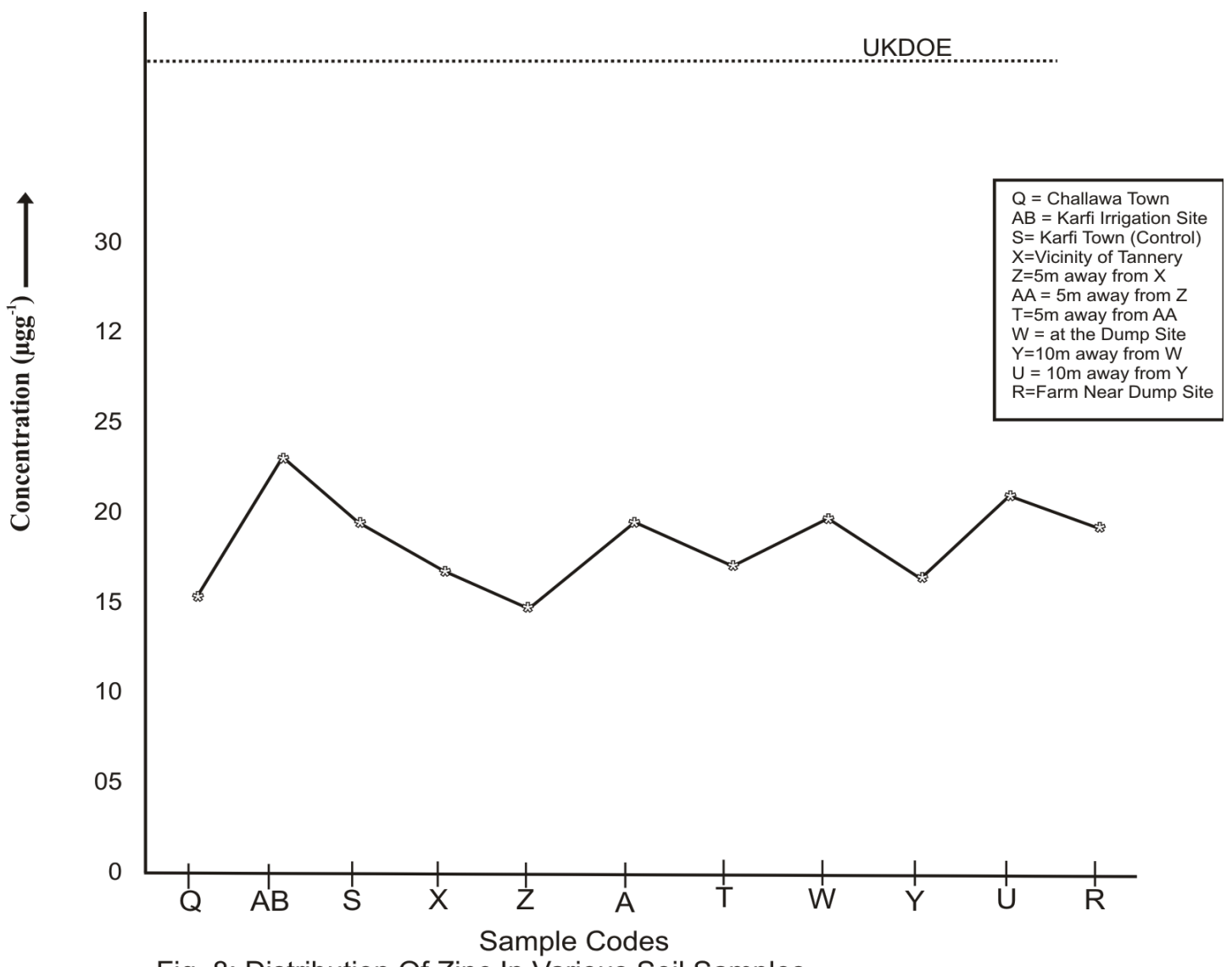

Fig. 8: Distribution Of Zinc In Various Soil Samples 


\section{CONCLUSION AND RECOMMENDATIONS}

From the result of the study, it is evident that soil contaminated by tannery waste at the dump site contained increased concentration of heavy metals which may reach toxic level through the food chain. This has been traced to many chemicals used for the tanning operations. It is therefore important that remediation of the soil be carried out to minimize the pollution and to render the polluted soil fit for agricultural use.

\section{REFERENCES}

Ademoroti C.M.A (1988). Environmental Management. Case Study of Industrial Waste Treatment . Evans Brothers Ltd Pp. 200-204.

Aluko, O. O., Sridhar, M.K.C. and Oluwande, P.A. (2003). Characterization of leachates from municipal solid waste/and fill site in Ibadan Nigeria. Journal of Environmental Health Research . 2 pp 13-17.

Asia, I.O., Jegede, S. I. Jegede, D. A., Ize-Iyamu, O.K. and Akpasubi, E. B.(2007). The effect of petroleum exploration and production operations on heavy metals contents of soil and ground water in the Niger delta. Int. J. Physical Sciences. 2 (10): 274-278

Bowen, H.J.M. (1979). Environmental Chemistry of the Element. Academic press London Pp . 79.

Butler J.D. (1970) . Air Pollution Chemistry. Academic Press London PP. 1-20.

Dara, S.S. (1993). A Textbook of Environmental Chemistry and Pollution Control. S. Chard and Company Ltd. Ram Nagar, New Delhi 110055 .

Dikko, A.U. and Ibrahim, S.A. (1999). Evaluation of Soils in Wurno Irrigation Project Area with respect to Salinity-Sodicity Hazards. Journal of Sustainable Agricultural Environment.(2): 256-261.

Duffus, J.H. (1980). Encyclopedia America International $14^{\text {th }}$ edition pp. 497.

Eddy, N.O. (2004). Physio-chemical parameter of water and heavy metals content of water, sediment and fishes from Qua Ibeo River estuary, Michael Okpara University of Agriculture, Umudike, Nigeria (Unpublished MSc Thesis) .

Folaranmi, F., Ajibola, U. O. and Adegoke, D. (2002). "Up fake and accumulation of some metals by spinach". Journal of tropical Bio science. 2(1): 41-44.

Gustav, R. (1974). Hazards Heavy Metals WHO International Reference Centre for Waste Disposal (IRCNDNEWS) no. 6.
Plants and grains produced from the farmlands around Challawa industrial area and very close to the dump sites needs to be analyzed for heavy metals. The plants growing at Challawa irrigation sites and the vegetables produced also need to be considered because the industrial effluents have been the source of water for irrigation purposes which is untreated or partially treated in the industrial plants.

Hawkes, S. J. (1997) "What is heavy Metal?" Journal of Chemical Education, 74:1374.

Higgens, I. H. and Burns, R. G. (1979). The Chemical and Microbiology of Pollution, $3^{\text {rd }}$ edition PP. 88-89. University of Kent Canterbury .

Jimoh, W.L.O. and Imam Mohammed (2011). Analysis of Iron and Zinc in Soil and Spinach grown in irrigated farmland of Kaduna metropolis Nigeria. International Journal of Research in Chemistry and Environment 1(2):141-146.

Jun, U. (1969) Mina Mata Disease and water pollution by industrial wastes. Rev. Int. Ocean Org. Med. Nos. XII-XIV.

Jun, U. (1974). Hazardous Heavy Metals IRCWD news No. 6 WHO International Conference for Waste disposal.

Kashem, M. A. (1996). Heavy metal contamination of terrestrial ecosystem in the vicinity of industries. A case study of Dhaka, Bangladesh. MSc Thesis Center of International Environment and Development Studies, Noragic Agric University of Norway.

Naidu, R., Willet, I. R., Kookana, R., Ramasamay, K. and Mahimairajah, S. (2000). "Towards better management of soils contaminated with tannery waste", Proceeding of a Workshop held in Coimbatore India.

United State Environmental Protection Agency (USEPA 1993). Standard for the use and disposal of sewage sludge. Final rules (40 CFR parts 257, 403 and 503). Federal Registration, 58.

UK Department of Environment (1987). Guidelines for disposal of sewage and its use. 